\title{
Editorial on the occasion of the International Congress of Nutrition. World hunger: A good fight or a losing cause?
}

This month, October 2009, is also the occasion of the International Congress of Nutrition (ICN), held every four years, this time in Bangkok. The theme of the Congress is 'Nutrition Security For All'. Sadly, as with 'Health For All in the Year 2000', this was a title that needed a question mark, or a qualifying statement such as 'Reality, Vision or Fantasy?' For since the theme of the Congress was fixed, the current global financial and fuel crises have increased world food insecurity. More populations and communities are short of food, more cannot look after their own family needs, and more are hungry. These linked crises are reducing the income and the work opportunities of the poor, most of all, and making their daily food less accessible and more expensive ${ }^{(1)}$.

Food security has improved in some lower-income countries, such as many in Latin America and the Caribbean, but the opposite is true in most other countries and regions. In sub-Saharan Africa, in particular, food insecurity has worsened by $32 \%$ since 2008. Now over one billion people worldwide are undernourished, an increase of $12 \%$ since $2008^{(1)}$. The consequences are bleak. Food insecurity is a prime cause of all sorts of other insecurities: more disease, more displacement and destitution, and more wars.

\section{A global public health crisis}

The only realistic attitude to the current world food security crisis is to realise that global systems of governance have contributed to the crisis. In the words of Dr Asha-Rose Migiro, Deputy Secretary-General of the UN: 'Our system of growing, distributing, and selling food is not serving us well ${ }^{(2)}$. And in an address to the Economic and Social Council in July, this is what Margaret Chan, WHO Director-General, had to say: 'The financial crisis is unprecedented because it occurs at a time of radically increased interdependence among nations. The consequences have been highly contagious, moving quickly from one country to another, and from one sector of the economy to many others.... Global trends, such as the industrialisation of food production and the globalisation of its marketing and distribution, help feed the world. But these trends have also contributed to a public health crisis. .... A focus on health as a worthy pursuit for its own sake is the surest route to that moral dimension that is so sadly lacking in international systems of governance, ${ }^{\text {(3) }}$.

Food insecurity is a problem not because of insufficient food, but because of inequitable access to food brought about by international systems of governance. As with climate change and natural resource depletion, it may now be time to acknowledge that equitable access to adequate, safe, nourishing food at a global level is an impossible dream, or at least a rapidly losing cause. Dealing with food insecurity now demands radical new thinking and action. Certainly, tinkering will not work.

Ban Ki-moon, Secretary General of the UN, has established a High-Level Task Force on the Global Food Security Crisis. Its Comprehensive Framework for Action (CFA) proposes two sets of actions ${ }^{(4)}$. The first is immediate. This focuses on meeting immediate needs: emergency food assistance; nutrition interventions and safety nets to be enhanced and made more accessible; among vulnerable populations, smallholder farmer food production to be boosted; trade and tax policies to be revised; and the macroeconomic implications to be managed.

The second set of actions is medium- to longer-term. These seek to build resilience in the systems that determine relative levels of global food and nutrition security. Social protection systems need to be expanded; smallholder farmer-led food availability growth needs to be sustained; and international food markets need to be made more equitable.

Can these ambitious proposals, some of which overturn policies that have been active as recently as 2008, succeed in a world whose resources are draining away? Are those responsible for governance at all levels, from global to local, ready to see that equitable food security is critical, and to act on it?

The moral aspects of food insecurity, hunger and starvation call for even deeper understanding and action. For example, global industrial meat production has grown rapidly in the last 20 years, heavily subsidised by the governments of rich countries ${ }^{(5)}$. In addition to draining water resources and increasing greenhouse gases, industrial meat production also means that most corn and soya production is used to feed cattle, pigs and chickens - an extremely inefficient means of producing food calories, and also a striking irony given our current food insecurity crisis.

When the World Trade Organization acts to overturn unfair systems of agricultural support and small and family farmers have fair access to credit and markets, we will have begun to address some of the root causes of world hunger. Production of novel, expensive, nutrientenriched foods by global food companies does not... 


\section{Commitment and action}

By ourselves, we in the nutrition profession cannot solve these problems. But we need to be involved, and we can be part of their solution. We need to see and agree on the immensity of our responsibilities as professionals and citizens.

So what to do? On 1 May this year the World Federation of Public Health Associations adopted its Istanbul Declaration, on the purpose and place of public health in today's world (http://www.wfpha.org). The tone of the Declaration is emphatic and imperative: Now is the time for all who affect the lives of others, working in government, industry, and in civil society, and as health care workers, academics, community and faith-based leaders, and citizens, to affirm the fundamental and elemental importance of public goods, including public health, and to assert and practice the basic human values of solidarity, sustainability, morality, justice, equity, fairness and tolerance'. The world public health community is gearing up, and so must the nutrition community.

Participants at the Bangkok ICN will no doubt leave the conference in a suitably sombre mood, and rightly so. As a profession we need to agree that world hunger is about more than lack of nutrients. The fundamental issues are about justice and morality. But discussion is not enough. At the very least, as we suggested in a previous editorial $^{(6)}$, a position document that will serve as a backbone for future work - a 'Bangkok Declaration' - is an essential next step for the international nutrition community to agree.

Agneta Yngve
Barrie Margetts
Roger Hughes
Marilyn Tseng
Editor-in-Chief and Deputy Editors

\section{References}

1. Food and Agriculture Organization of the United Nations (2009) More people than ever are victims of hunger. Background document. http://www.fao.org/fileadmin/ user_upload/newsroom/docs/Press\%20release\%20june-en.pdf (accessed July 2009).

2. Migiro A-R (2009) Sowing the seeds of an African agricultural revival. http://www.un.org/issues/food/taskforce/ dsg_oped_July_09.shtml (accessed July 2009).

3. Chan M (2009) Focus on health is the key to welfare of humanity. Address to the Economic and Social Council 2009 High-level Segment, Geneva, 6 July. http:// www.who.int/dg/speeches/2009/health_focus_20090706/en/ (accessed July 2009).

4. Ki-moon B, Diouf J, Holmes J \& Nabarro D (2008) HighLevel Task Force on the Global Food Security Crisis. Comprehensive Framework For Action, July 2008. http:// www.un.org/issues/food/taskforce/Documentation/CFA\% 20Web.pdf (accessed July 2009).

5. Bittman M (2008) Rethinking the Meat-Guzzler. The New York Times, 27 January.

6. Yngve A (2009) Making the best of international conferences (Editorial). Public Health Nutr 12, 1309-1310. 